The Care of Long-term Prisoners 


\section{The Care of Long-term Prisoners}

Renée Short

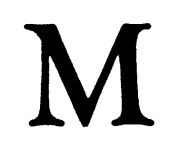


(C) Renée Short 1979

Softcover reprint of the hardcover 1st edition 1979 978-0-333-24274-2

All rights reserved. No part of this publication may be reproduced or transmitted, in any form or by any means, without permission.

First published 1979 by

THE MACMILLAN PRESS LTD

London and Basingstoke

Associated companies in Delhi Dublin

Hong Kong Johannesburg Lagos Melbourne

New York Singapore and Tokyo

British Library Cataloguing in Publication Data

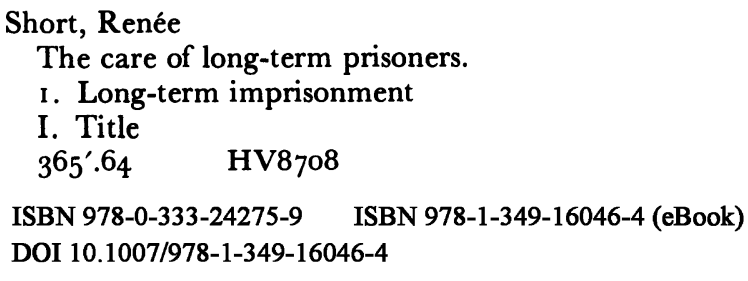

This book is sold subject to the standard conditions of the Net Book Agreement.

The paperback edition of this book is sold subject to the condition that it shall not, by way of trade or otherwise, be lent, resold, hired out, or otherwise circulated without the publisher's prior consent, in any form of binding or cover other than that in which it is published and without a similar condition including this condition being imposed on the subsequent purchaser. 


\section{Contents}

Acknowledgements vii

Introduction ix

I. United States : Riots and Reforms I

Women in American Prisons $\quad$ I.2

The Greatest Frustration of All—Sexual Deprivation $\quad$ I6

The Alternative-Conjugal Visits $\quad 19$

2. Sweden: Liberation within Bounds 32

The 'Thieves Parliament' 34

Kumla Central Prison $\quad 38$

Modern Factory Conditions in Prison 44

The Treatment of Women Offenders $\quad 46$

Unsupervised Visits in Swedish Prisons 47

3. Holland : Keeping People out of Prison 50

Sentencing Policy in Holland 5 I

The Treatment of Dangerous Offenders $\quad 54$

Contact with the Community 57

Attitudes of Prison Officers and Police $\quad 59$

4. Finland : More Alcoholism than Murder 63

Labour Colonies $\quad 63$

Long-term Prisoners $\quad 65$

Hämeenlinne and Nummenkylä Prisons 66

5. Mexico: Poverty and Progressivism 69

Conjugal Visits $\quad 70$

Sta Marta Acatitla Prison at Ixtapalapa $\quad 7$ I

Almolya de Juarez Prison at Toluca $\quad 75$ 
6. Greece: Fertile Ground for Reform 80 $\begin{array}{ll}\text { Prison Staff } & 83\end{array}$ The Women's Prison $\quad 84$ The Prison Farm at Tiryns $\quad 86$

7. Britain: Old-fashioned Ideas in a Modern Society 90 The Prison-building Programme $\quad 96$ Prison Staff $\quad 100$ The Prisoner's Working Day 104 $\begin{array}{ll}\text { Education and Vocational Training } & 107\end{array}$ $\begin{array}{ll}\text { Security } & \text { I09 }\end{array}$ Prison Medical Services 1 I I Grendon Underwood Psychiatric Prison $\quad$ I 3 Women in Prison $\quad$ I 6 Pregnant Women in Prison $\quad$ I 8

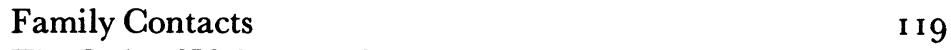
The Role of Voluntary Organisations $\quad$ I 23 Research $\quad$ I 26 The Custody of Dangerous and Abnormal Offenders I 3 I Family and Community Contacts The Parkhurst Riot $\quad 135$

A Prison Experiment in Scotland $\quad$ I 39 Northern Ireland Prisons $\quad 145$

8. Towards a Better Prison System 151 Appendix: Organisations Receiving Home Office Grants for Hostels $15^{6}$ Notes and References $\quad$ I 59 


\section{Acknowledgements}

The general public considers that the role of the prison is to punish. Punishment of offenders is the function of the courts. The prison has to implement the punishment imposed by the court by depriving the offender of his liberty. It has another function-the much more difficult one of treating the offender so that he will lead a 'good and useful life' on release.

This book is an attempt to compare methods of treating long-term offenders in several different countries and to show that harsh, punitive treatment, far from assisting rehabilitation, is counter-productive and neither eliminates nor contains violence within the prison.

Despair and frustration at the beginning of a long sentence, particularly among the immature, can lead to violence. Good psychiatric care is essential to help long-term prisoners to settle down.

In some countries prisoners have demonstrated remarkable maturity, developing artistic and intellectual ability hitherto unnoticed, when given the responsibility of decision-making within the prison.

The greatest problem must be that of maintaining human relationships and family contacts, essential to the rehabilitative process.

The author hopes the examples here described as practised in those countries with an enlightened prison system will encourage others to follow their example.

She acknowledges with deep gratitude the help given by Ministers in many countries, and their officials, including the Home Office and the Scottish Office, who arranged many prison visits, and 
the help given by prison staff and prisoners who talked freely about their problems and aspirations. Thanks are due to the Library staff at the British House of Commons and at the United States Embassy Library in London for the collection of much background reading material. 


\section{Introduction}

A confidential memo to an American foundation supporting a grant for the study of the U.S. prison system said 'most of the recent attention to the criminal law process has been in the nature of a pre-occupation with stopping crime and catching convicted criminals. Once a criminal is caught and tried and incarcerated, interest wanes ... The general public seems to care little about prisons and prisoners, wrongly assuming that the issues they raise concern only questions of punishment or deterrence.'

That is true in Britain today. Proposals for prison reform, for a more humane prison system and for the rehabilitation of criminals meet with apathy or outright opposition. There are no votes to be won in campaigning for a better prison system and therefore no political party says much about it in its election manifesto. Yet the evidence of the failure of the present system is clear from the high rate of recidivism almost all over the world, the poor results of such rehabilitation as exists and the pressure for more research and experiment from those working within the prison system.

Those who demand punishment as well as imprisonment oppose all efforts to humanise the system by saying 'If we make our prisons like four-star hotels, they'll never be empty!' They never are! If only the penal system had been able to deter, the crime rate everywhere would be negligible. Sadly, we know that well over half the convicted criminals continue with crime after their release, returning to prison again and again, and the crime rate continues to rise. Clearly the removal of a prisoner's freedom and 
his civil rights does not deter. Restrictions on writing and receiving letters, and on visits, weigh particularly heavily on all prisoners. Gross overcrowding, lack of proper washing and sanitary facilities and of privacy, after the initial shock of the conditions, have a brutalising rather than a rehabilitative effect, especially on longterm prisoners. Most British prisons (like many hospitals) were built during Queen Victoria's reign, yet the capital resources to improve or rebuild them are pitiably inadequate.

Public opinion is not interested and so little is done to relieve the appalling conditions inside many British prisons. We still condemn 12 per cent of male prisoners to live three to a cell originally built for one; we still condemn the majority of male prisoners to the indignity and stench of the morning slopping-out because it would cost too much to provide proper lavatories; we still regard one bath a week as adequate; cleanliness is not next to godliness in prison-and in the majority of our old prisons we still regard it as a good return for a prison officer's pay that he spends a large part of his working day locking and unlocking doors instead of teaching, advising, discussing personal problems or carrying out any other rehabilitative process.

The serious overcrowding could be relieved by the removal of drug addicts (but not pushers), alcoholics, prostitutes and some male sex offenders from prison altogether. Certainly drug addicts, alcoholics and some sex offenders require psychiatry and treatment instead of imprisonment. Little or no treatment is given to these offenders in prison because of the shortage of psychiatrists and others qualified to give it. Because of the inadequacies of the National Health Service and of community care, and because of public attitudes, hospitals are unable or unwilling to treat such cases and so many return to prison over and over again, serving their sentence and committing similar offences as soon as they are released.

The prison system, therefore, has become the repository of the failures of our social system - of education, housing, religion, mental care, all of which fail to treat or help the thousands of inadequate personalities in our midst.

These men and women become assimilated within the prison system - 'prisonised '1 _ absorbing the language, customs, habits and culture of prison. Prisoners serving their first sentence inevitably slip into the pattern after a while; if it is a short sentence, they 
may suffer little damage, serving their time, getting a job and putting that period of their lives behind them. Others may return more sophisticated, more experienced members of the prison culture, knowing the dodges, hating the prison staff, behaving in an abnormal way sexually, with their criminality and anti-social behaviour increased.

All prisoners suffer the loss of liberty; they are confined to a small area within the prison; they are isolated from their families, from normal sexual relationships and from loving contact with wives, children and girlfriends. They miss their familiar surroundings and their personal possessions; their sense of deprivation is acute even though they are adequately clothed and fed. They can no longer make decisions and they must abide by rules and regulations made by others-as they did when they were children. Weaker prisoners see themselves at the mercy of the bullies, the perverts and the violent. Many live in constant fear of attack in prison.

The problem of long-term prisoners is a serious one. How can these prisoners be managed? How do other countries deal with similar problems and similar offenders? What lessons can we learn from them?

This book will attempt to examine the achievements of advanced and less advanced countries and the changes introduced by them. We may have something to learn, perhaps, from sources that may surprise us! 
I know not whether Laws be right, Or whether Laws be wrong;

All that we know who be in gaol Is that the wall is strong;

And that each day is like a year, A year whose days are long.

The vilest deeds like poison-weeds Bloom well in prison air;

It is only what is good in Man That wastes and withers there:

Pale anguish keeps the heavy gate And the Warder is Despair.

\author{
Oscar Wilde \\ 'Ballad of Reading Gaol'
}

